\title{
QUINCE 'CPP': NEW DWARF ROOTSTOCK FOR PEAR TREES ON ORGANIC AND HIGH DENSITY PLANTING ${ }^{1}$
}

\author{
RENATO VASCONCELOS BOTELHO ${ }^{2}$, EVERTON SCHNEIDER ${ }^{3}$ \\ DANIELLE MACHADO ${ }^{3}$, RAFAEL PIVA ${ }^{4}$, ANDRICIA VERLINDO $^{5}$
}

\begin{abstract}
In Brazil, pear production presents the same incipient situation over the last 15 years, due mostly to low production technology. In this context, this study aimed to evaluate the development, growth and production of the pear tree cultivars Cascatense, Tenra and Hosui grafted on 'CPP' quince rootstock, using 'FT' pear as interstem. This trial was carried out in Guarapuava, State of Paraná, Southern region of Brazil, by five productive cycles. The pear trees were planted in September of 2004, spaced at $1.0 \times 4.0 \mathrm{~m}(2,500$ trees $\mathrm{ha}^{-1}$ ), trained to the modified central leader, on a Four-wire trellis, with drip irrigation and cultivated under organic production system. The following variables were evaluated: sprouting, anthesis, yield, fruit weight, soluble solids content, titratable acidity, pulp firmness, canopy area per plant and per hectare and trunk diameter. The pear tree cv. Tenra was outstanding most of the years for fruit yield, and, consequently, showed the highest accumulated yield over the period $\left(51.6 \mathrm{t} \mathrm{ha}^{-1}\right)$, followed by the cultivars Cascatense (39.7 $\mathrm{t} \mathrm{ha}^{-1}$ ) and Hosui $\left(18.7 \mathrm{t} \mathrm{ha}^{-1}\right)$. All pear cultivars presented suitable physical-chemical characteristics for commercial purposes, with minimal average soluble solids content of $11 \%$ at harvest. The maximum canopy area per hectare was attained for $\mathrm{cv}$. Cascatense $\left(3063.2 \mathrm{~m}^{2}\right)$, that was considered insufficient for a high yield. These results suggest the needs for studies with higher density planting and other training systems, searching optimize canopy volume. One of the most limiting factors in the organic pear orchard was the incidence of pear dieback caused by Botriosphaeria dothidea, severe more often in pear trees cv. Hosui.

Index terms: Pyrus spp., Cydonia oblonga, agroecology, phenology, deciduous fruits.
\end{abstract}

\section{MARMELEIRO 'CPP’: NOVO PORTA-ENXERTO ANÃO PARA PEREIRAS EM PLANTIOS ORGÂNICOS E EM ALTA DENSIDADE}

RESUMO - No Brasil, a produção de peras apresenta a mesma situação incipiente dos últimos 15 anos, devido principalmente à baixa tecnologia de produção. Neste contexto, o objetivo do presente trabalho foi avaliar o crescimento, o desenvolvimento e a produção das cultivares de pereira Cascatense, Tenra e Hosui enxertadas sobre o porta-enxerto marmeleiro 'CPP', utilizando como interenxerto a pereira 'FT'. O experimento foi conduzido em Guarapuava, Paraná, por cinco ciclos produtivos. As pereiras foram plantadas em setembro de 2004, espaçadas em 1,0 x 4,0 m (2.500 plantas ha $\left.^{-1}\right)$, conduzidas em sistema de líder central modificado, em espaldeira com quatro fios, irrigação por gotejamento e sistema de produção orgânica. As seguintes variáveis foram avaliadas: brotação, florescimento, produtividade, massa dos frutos, teor de sólidos solúveis, acidez titulável, firmeza da polpa, área da copa por planta e por hectare, e diâmetro do tronco. A pereira cv. Tenra foi superior na maioria dos anos para a produção de frutos e, consequentemente, apresentou a maior produtividade acumulada no período $\left(51,6 \mathrm{tha}^{-1}\right)$, seguida pelas cultivares Cascatense $\left(39,7 \mathrm{t} \mathrm{ha}^{-1}\right)$ e Hosui $\left(18,7 \mathrm{t} \mathrm{ha}^{-1}\right)$. Todas as cultivares de pera apresentaram características físico-químicas adequadas para comercialização, com média mínima de teor de sólidos solúveis de $11,0 \%$ na colheita. A máxima área de copa por hectare foi atingida pela $\mathrm{cv}$. Cascatense $\left(3.063,2 \mathrm{~m}^{2}\right)$ e considerada insuficiente para se obter alta produtividade. Estes resultados indicam a necessidade de estudos com maiores densidades de plantio e outros sistemas de condução, buscando otimizar o volume da copa. Um dos maiores fatores limitantes da produção de peras orgânicas foi a incidência do cancro da pereira causada por Botriosphaeria dothidea, mais frequentemente severo em pereiras cv. Hosui.

Termos para indexação: Pyrus spp., Cydonia oblonga, agroecologia, fenologia, frutas de clima temperado.

1(Trabalho 145-11). Recebido em: 13-05-2011. Aceito para publicação em: 29-05-2012.

${ }^{2}$ Eng. Agr. Dr. Prof. Adjunto. Departamento de Agronomia, Universidade Estadual do Centro-Oeste - Unicentro. R. Simeão Camargo Varella de Sá no 03, CEP 85040-080, Guarapuava-PR. E-mail: rbotelho@unicentro.br. Bolsista PQ-2 CNPq.

${ }^{3}$ Alunos de Graduação em Agronomia, Universidade Estadual do Centro-Oeste - Unicentro. E-mails: verto007@hotmail.com, mdaniielle@gmail.com. Bolsista PIBIC/CNPq

${ }^{4}$ Eng. Agr. Mestrando em Agronomia. Universidade Estadual do Centro-Oeste - Unicentro. Bolsista CAPES. E-mail: raffaelepiva@gmail.com ${ }^{5}$ Eng. Agr. Mestranda em Agronomia. Universidade Estadual do Centro-Oeste-Unicentro. Bolsista CNPq. E-mail: andriciaverlindo@hotmail.com. 


\section{INTRODUCTION}

The pear is the third most produced deciduous fruit in the World, after grapes and apples, with a production of 21.9 million $t$ in 1,739 thousand hectares (FAO, 2010). It is also the first fresh fruit imported by Brazil. From 2001 to 2005, it was imported in average 90,296.7 $\mathrm{t}$ and expended US\$ 41,235.4 per year (FIORAVANÇO, 2007).

In Brazil, the pear production presents the same incipient situation over the last 15 years, with a production of 1,600 $\mathrm{t}$ and cultivated area below $2,000 \mathrm{ha}$. The yield is also very low, around $11.0 \mathrm{t}$ $\mathrm{ha}^{-1}$, volume much lower than neighbor countries, such as Argentina and Chile, with 30.0 and $26.5 \mathrm{t}$ $\mathrm{ha}^{-1}$, respectively (FAO, 2010).

Its expansion in Brazilian territory has found some obstacle due to low production technology; indefiniteness or even inexistence of scion/ rootstock combinations adapted to the different potentially producer regions and; the lack of nursery trees to attend the fruitculturists (FIORAVANÇO, 2007).

According to Wertheim et al. (2001), worldwide, new apple and pear orchards are planted more intensively than a few decades ago. Reasons for this trend toward high-density planting (HDP) are universals: earlier return on capital, economizing in labor input and producing a high yield of quality fruits. One of the exigencies of HDP is dwarfing rootstocks.

The most commercially viable dwarfing rootstocks for pears are clones of quince. Trees on quince rootstocks are reduced in vigor, precocious and productive in cropping and, in most cases, bear fruits of good size and quality. Pears growers in Western Europe use trees propagated on Malling (EM) Quince C, Adams, A or BA29 clone quince rootstock (WEBSTER, 2001). Nevertheless, the results with dwarf rootstocks for pears have been inconstant around the World (CARRERA et al., 2005; POLICARPO et al.; 2006; STERN and DORON, 2009).

In this context, this experiment aimed to verify growth, development and fruit production of different pear cultivars grafted on 'CPP' quince rootstock in the Middle-Southern region of the State of Parana, Brazil.

\section{MATERIAL AND METHODS}

This trial was carried out in the experimental orchard of The State University of the MiddleWestern Region (Unicentro), in Guarapuava, State of

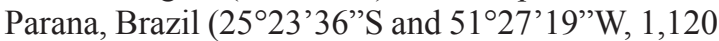
$\mathrm{m}$ a.s.l.). This region has a Subtropical Highland Climate $(C f b)$, according to the Köppen classification, with accumulated chilling hours over the winter around 300 hours $\left(\leq 7.2^{\circ} \mathrm{C}\right)$. The soil is classified as Brown Latosol distroferric.

In this experiment, it was evaluated the phenology, development and fruit production of the pear cultivars Cascatense, Tenra and Hosui grafted on 'CPP' quince rootstock with pear ' $\mathrm{FT}$ ' interstem. Both rootstock and interstem were developed by the nursery 'Clone' (Araucária, Paraná, Brazil). The pear trees were planted in September of 2004, spaced at $1.0 \times 4.0 \mathrm{~m}\left(2,500\right.$ trees $\left.\mathrm{ha}^{-1}\right)$, trained to the Modified Central Leader System on a four-wire trellis, with drip irrigation and cultivated under organic production system.

The organic fertilization was preferentially adopted, using materials easily found in the production region (animal manures, agricultural and agroindustry residues, green manures) in quantities previously estimated according to trees needs and diagnosis (plant and soil analysis). Other no-organic sources allowed in Organic Production system were used in function of soil fertility and plant exigencies (CQFS-RS/SC, 2004), such as: rockdusts, lime and natural phosphates. For pest control, it was used allowed products, such as: neem oil, chinaberry extract, bordeaux mixture, lime-sulfur, garlic extract and attractive traps. An average of 16 sprays was done for pests control in each vegetative cycle. For dormancy release it was applied an aqueous solution at $30 \mathrm{~mL}$ $\mathrm{L}^{-1}$ of garlic extract and $20 \mathrm{~mL} \mathrm{~L}^{-1}$ of mineral oil.

The experimental design was in randomized blocks, with three treatments (pear cultivars), five replications and five-plant per plot. Each experimental block was composed by one planted line.

From 2004 to 2010 it was evaluated the following variables:

1) Sprouting: Two branches per plant was previously marked and evaluated for percentage of sprouted buds.

2) Anthesis: two branches per plant was previously marked and evaluated weekly for the number of opened flowers. The results were used to estimate the percentage of anthesis.

3) Yield (t ha-1): All fruits of each experimental plot were weighted in precision balance and the total yield was calculated in function of the planting density, expressed in tonnes per hectare.

4) Average fruit weight: Calculated for each experimental plot in function of the number of clusters and total yield, expressed in grams.

5) Soluble solids content: After harvest, a sample of 10 fruits per experimental plot was used for analysis with an automatic temperature compensation refractometer

6) Titratable acidity: An aliquot of $5 \mathrm{~mL}$ of pear juice (10 fruits) was titrated with $\mathrm{NaOH} 0.1 \mathrm{~N}$, and the equivalent-gram of malic acid was calculated and expressed as percentage. 
7) Fresh firmness: Firmness was measured objectively on two sides of each fruit after a thin slice of skin was removed using a Fruit Texture Analyzer fitted with an $8 \mathrm{~mm}$ probe.

8) Canopy area per plant and per hectare: Diameter (D) and height $(\mathrm{H})$ of the canopy were measured every year in April and, from these results the canopy area per plant $(\mathrm{DxH})$ and per hectare (DxHx2,500) were estimated (EBERT and RAASCH, 1987).

9) Trunk diameter: Every year in April, the trunk diameter was measured $20 \mathrm{~cm}$ above grafted union.

All data were analyzed statistically using the ANOVA in the Sisvar 5.1 statistical package (Ferreira, 2008). Meaningful comparisons were generated using Tukey`s test ( $5 \%$ level).

\section{RESULTS AND DISCUSSION}

The sprouting percentage data of pear trees grafted on 'CPP' quince rootstock, during five cycles are presented in Figure 1. It was verified differences of dates and sprouting percentage between cultivars and cycles. Particularly, in 2008, the climate was very atypical, with a warm end of winter and cold beginning of spring, what decreased considerably the bud sprouting. In general, cv. Cascatense showed the earliest dormancy release, with sprouting concentrated mostly in August, followed by cv. Tenra, with bud sprouting extending from August until beginning of September. The cv. Hosui presented sprouting a little later, starting in September and some cycles finishing just in November. In relation to anthesis, the cv. Cascatense was the earliest with flowering concentrated in the second-half of August and beginning of September. For highland areas as most part of Guarapuava region, this feature is not appropriate, once this region usually has hazard chilling temperatures in the beginning of spring.

The cv. Tenra also started anthesis in August, but it was extended to the followed months, depending on the cycle, which is considered a good characteristic for pollination purposes. The cv. Hosui showed anthesis mostly concentrated in September (Figure 2).

These results are similar to other reports. For pear trees cv. Cascatense, Nakasu and Faoro (2003) described flowering in the second-half of August in the southern region of Brazil. According to Ribeiro et al. (1991), for the conditions at the Plateau of the State of Santa Catarina, pear trees cv. Hosui started sprouting in the beginning of September, and flowering starting in Mid-September and ending in the beginning of October.

The pear tree cv. Tenra was outstanding in the most years for fruit yield, and, consequently, showed the highest accumulated yield $\left(51.6 \mathrm{t} \mathrm{ha}^{-1}\right)$, followed by the cultivars Cascatense $\left(39.7 \mathrm{t} \mathrm{ha}^{-1}\right)$ and Hosui $\left(18.7 \mathrm{t} \mathrm{ha}^{-1}\right)$. In the last evaluated cycle, the yields were 13.6 and $14.8 \mathrm{tha}^{-1}$, for cvs. Cascatense and Tenra, respectively, higher than the Brazilian average of $11.0 \mathrm{t} \mathrm{ha}^{-1}$ (FAO, 2010).

Many plants from cv. Hosui died in 2010 due to $B$. dothidea infection, what, together with flowers abortion due to chilling in early spring, not allowed fruit production in 2010/2011 cycle.

The pear cv. Cascatense showed the earliest fruit maturation with harvest between middle of December and beginning of January. The cvs. Tenra e Hosui usually presented harvest in the first-half of January. In most of the years cv. Cascatense presented the highest fruit weight, attaining an average of $189.0 \mathrm{~g}$, followed by Tenra (165.0 g) and Hosui (165.4 g).

The fruit maturity in the edafoclimatic conditions of Guarapuava-PR showed to be much earlier than other states from Southern region of Brazil. According to Nakasu and Faoro (2003) pears $\mathrm{cv}$. Cascatense presents fruit maturation in the middle of January, while Ribeiro et al. (1991) reported maturation of pears cv. Hosui in mid-February. These differences may be related to the warmer conditions in the spring and summer in the state of Paraná, but the quince rootstock could also modify fruit maturity. Robert et al. (2008) verified that pears 'Forelle' showed lower fresh firmness and higher soluble solids content when the trees were grafted on ' $\mathrm{A}$ ' and ' $\mathrm{C}$ ' quince rootstocks.

The data of physic-chemical fruit analysis are presented in Table 1. Pears cv. Cascatense showed the highest titratable acidity in all cycles with an average of $0.394 \%$ compared to $0.208 \%$ for $\mathrm{cv}$. Tenra and $0.140 \%$ in cv. Hosui. Soluble solids content varied each year, but pears cv. Hosui showed the highest average for this variable (11.7\%) compared to Tenra (11.0\%) and Cascatense (11.2\%). According to Marini (2009), the minimum soluble solids content to harvest for European pears is $10 \%$ and for Asian pears $12 \%$, although this maturity index is not very trustable, once it could be influenced by fruit bearing and climatic conditions.

In general, Hosui pears showed the lowest fresh firmness at harvest with average of $3.6 \mathrm{~kg} \mathrm{in}^{-2}$, followed by Tenra $\left(6.0 \mathrm{~kg} \mathrm{in}^{-2}\right)$ and Cascatense ( 8.0 $\left.\mathrm{kg} \mathrm{in}^{-2}\right)$. The most European pears cultivars must be harvest when fresh firmness reached between 8 and $9 \mathrm{~kg} \mathrm{in}^{-2}$. Usually, Asian pears are harvest when fresh firmness attained between 4 and $5 \mathrm{~kg} \mathrm{in}^{-2}$ (MARINI, 2009).

The data related to vegetative growth are presented in Table 2. In general, pear trees 'Cascatense' showed the highest vegetative vigor 
followed by cvs. Tenra and Hosui, reflecting in higher values for trunk diameter and canopy area per plant and per hectare. One of the most limiting factors for vegetative growth was the incidence of a fungus pathogen that causes branch or shoot blight on infected trees without producing blisters or warts on branches and twigs, and is referred to as pear dieback or shoot blight. Becker and Hiryuki (2002) identified the pathogen causing pear shoot blight as Botriosphaeria dothidea in Asian pears in the State of Santa Catarina, Brazil. Its incidence was verified widespread in pear trees cv. Cascatense in the cycle 2005/2006 and in cv. Hosui in 2008/2009 and 2009/2010, with many died plants. This disease incidence obligated the practice of intensive prunes and plants eradication. After pruning all the cuts were brushed with bordeaux paste.

The Canopy Area per Hectare in the end of the experiment was $3,063.2 \mathrm{~m}^{2}$ for Cascatense and
$2,446.4 \mathrm{~m}^{2}$ for Tenra, practically the same average of the last two cycles, demonstrating growth stagnation or the limit of vegetative development. According to Ebert and Raasch (1987) for the highest yield in apple orchards is necessary a canopy area of $5,000 \mathrm{~m}^{2} \mathrm{ha}^{-1}$, superior to the results attained in this trial for pear trees. These considerations could suggest the needs for studies with higher density planting and other training systems, optimizing canopy volume.

In a experiment carried out in many regions of Spain with the pear cv. Conference trained in slender spindle system with 4,000 plants ha ${ }^{-1}$ presented yield $9 \mathrm{t}$ higher when compared to 2,000 plants $\mathrm{ha}^{-1}$, fact that was associated to a interception light increase from 62 to 74\%. According to Wertheim et al. (2001), the planting density could be higher without interception light and fruit size commitment in system where the plants are distributed over superficies in three dimensions such as "Y" and "V" systems.

TABLE 1 - Yield, harvest date, mean fruit weight, soluble solids (SS), tritatable acidity (TA) and fresh firmness of pear cultivars grafted on 'CP' quince rootstock (Guarapuava, Parana, Brazil, 2005-2010).

\begin{tabular}{|c|c|c|c|c|c|c|c|}
\hline \multirow{2}{*}{ Cultivars } & $2005 / 06$ & $2006 / 07$ & $2007 / 08$ & $2008 / 09$ & $2009 / 10$ & $2010 / 11$ & Total \\
\hline & \multicolumn{6}{|c|}{ yield $\left(\mathrm{t} \mathrm{ha}^{-1}\right)$} & \\
\hline Cascatense & $0.43 \mathrm{~b}$ & $6.06 \mathrm{ab}$ & $11.03 \mathrm{a}$ & $4.76 \mathrm{ab}$ & $3.75 \mathrm{~b}$ & $13.64 \mathrm{a}$ & $39.68 \mathrm{a}$ \\
\hline Tenra & $3.73 \mathrm{a}$ & $9.41 \mathrm{a}$ & $7.13 \mathrm{a}$ & $7.21 \mathrm{a}$ & $9.33 \mathrm{a}$ & $14.78 \mathrm{a}$ & $51.60 \mathrm{a}$ \\
\hline Hosui & $0.94 \mathrm{~b}$ & $3.42 \mathrm{~b}$ & $8.48 \mathrm{a}$ & $3.07 \mathrm{~b}$ & $2.74 \mathrm{~b}$ & $0.0 \quad \mathrm{~b}$ & $18.66 \mathrm{~b}$ \\
\hline$\overline{\mathrm{CV}}(\%)$ & 54.64 & 36.97 & 32.50 & 35.32 & 23.66 & 38.79 & 19.60 \\
\hline \multirow[t]{2}{*}{ MSD } & 1.68 & 4.21 & 5.22 & 3.21 & 2.26 & 6.65 & 12.99 \\
\hline & \multicolumn{6}{|c|}{ harvest date } & \\
\hline Cascat & 16-Dec-06 & 26-Dec-06 & 11-Jan-08 & 05-Jan-09 & 06-Jan-10 & 16 -dec-10 & \\
\hline Tenra & 21-Jan-06 & 12-Jan-07 & 12-Jan-08 & 05-Jan-09 & 06-Jan-10 & 16 -dec-10 & \\
\hline \multirow[t]{2}{*}{ Hosui } & 21-Jan-06 & 12-Jan-07 & 13-Jan-08 & 05-Jan-09 & 06-Jan-10 & - & \\
\hline & \multicolumn{6}{|c|}{ Fruit weight (g) } & Mean \\
\hline Cascatense & $.7 \mathrm{a}$ & $148.2 b$ & $206.3 a$ & $268.3 \mathrm{a}$ & $236.7 \mathrm{a}$ & $172.4 \mathrm{a}$ & $189.0 \mathrm{a}$ \\
\hline Tenra & $113.2 \mathrm{a}$ & $189.4 \mathrm{a}$ & $144.8 \mathrm{~b}$ & $259.8 \mathrm{a}$ & $165.8 \mathrm{c}$ & $121.4 \mathrm{~b}$ & $165.7 \mathrm{~b}$ \\
\hline Hosui & $131.7 \mathrm{a}$ & $160.7 \mathrm{ab}$ & $143.6 \mathrm{~b}$ & $207.1 \quad b$ & $184.0 \mathrm{~b}$ & - & $165.4 \mathrm{~b}$ \\
\hline$\overline{\mathrm{CV}}(\%)$ & 21.95 & 12.34 & 8.49 & 13.58 & 3.67 & 14.15 & 2.86 \\
\hline \multirow[t]{2}{*}{ MSD } & 45.87 & 37.08 & 25.34 & 10.26 & 12.98 & 24.98 & 8.97 \\
\hline & \multicolumn{6}{|c|}{ SS (\%) } & Mean \\
\hline Cascatense & $9.0 \mathrm{~b}$ & $10.2 \mathrm{~b}$ & $11.2 \mathrm{a}$ & $13.5 \mathrm{a}$ & $11.8 \mathrm{a}$ & 11.2 & $11.2 \mathrm{~b}$ \\
\hline Tenra & $10.0 \mathrm{ab}$ & $10.4 \mathrm{~b}$ & $11.3 \mathrm{a}$ & $11.5 \mathrm{~b}$ & $11.4 \mathrm{a}$ & 11.1 & $11.0 \mathrm{~b}$ \\
\hline Hosui & $10.5 \mathrm{a}$ & $11.2 \mathrm{a}$ & $11.6 \mathrm{a}$ & $12.1 \mathrm{~b}$ & $12.8 \mathrm{a}$ & - & $11.7 \mathrm{a}$ \\
\hline$\overline{C V}(\%)$ & 5.83 & 3.03 & 3.47 & 5.75 & 6.58 & 7.32 & 2.04 \\
\hline \multirow[t]{2}{*}{ MSD } & 1.04 & 0.58 & 0.71 & 12.38 & 1.43 & 0.98 & 0.42 \\
\hline & \multicolumn{6}{|c|}{ TA (\%) } & Mean \\
\hline Cascat & $0.466 \mathrm{a}$ & $522 a$ & $0.317 \mathrm{a}$ & $0.228 \mathrm{a}$ & $0.347 \mathrm{a}$ & $0.492 \mathrm{a}$ & $0.394 \mathrm{a}$ \\
\hline Tenra & $0.208 \mathrm{~b}$ & $0.202 \mathrm{~b}$ & $0.289 \mathrm{ab}$ & $0.136 \mathrm{~b}$ & $0.203 \mathrm{~b}$ & $0.221 \mathrm{~b}$ & $0.208 \mathrm{~b}$ \\
\hline Hosui & $0.150 \mathrm{~b}$ & $0.150 \mathrm{~b}$ & $0.154 \mathrm{~b}$ & $0.118 \mathrm{~b}$ & $0.138 \mathrm{c}$ & - & $0.140 \quad \mathrm{c}$ \\
\hline$\overline{\mathrm{CV}}(\%)$ & 25.58 & 19.44 & 30.65 & 13.27 & 8.67 & 11.12 & 11.41 \\
\hline \multirow[t]{2}{*}{ MSD } & 0.127 & 0.025 & 0.035 & 0.039 & 0.036 & 0.047 & 0.051 \\
\hline & \multicolumn{6}{|c|}{ fresh fimness $\left(\mathrm{kg} \mathrm{in}^{-2}\right)$} & \\
\hline Cascatense & $11.9 \mathrm{a}$ & $9.2 \mathrm{a}$ & $6.5 a$ & & $6.0 \mathrm{a}$ & 6.89 & $8.0 \mathrm{a}$ \\
\hline Tenra & $6.4 \mathrm{~b}$ & $5.4 \mathrm{~b}$ & $5.7 \mathrm{a}$ & - & $6.0 \mathrm{a}$ & 6.29 & $6.0 \mathrm{~b}$ \\
\hline Hosui & $3.3 \mathrm{c}$ & $4.3 \mathrm{c}$ & $3.6 \mathrm{~b}$ & - & $3.0 \mathrm{~b}$ & - & $3.6 \mathrm{c}$ \\
\hline$\overline{\mathrm{CV}}(\%)$ & 6.24 & 5.68 & 9.41 & - & 7.51 & 16.22 & 4.71 \\
\hline MSD & 0.81 & 0.648 & 0.893 & & 0.682 & 1.29 & 0.500 \\
\hline
\end{tabular}



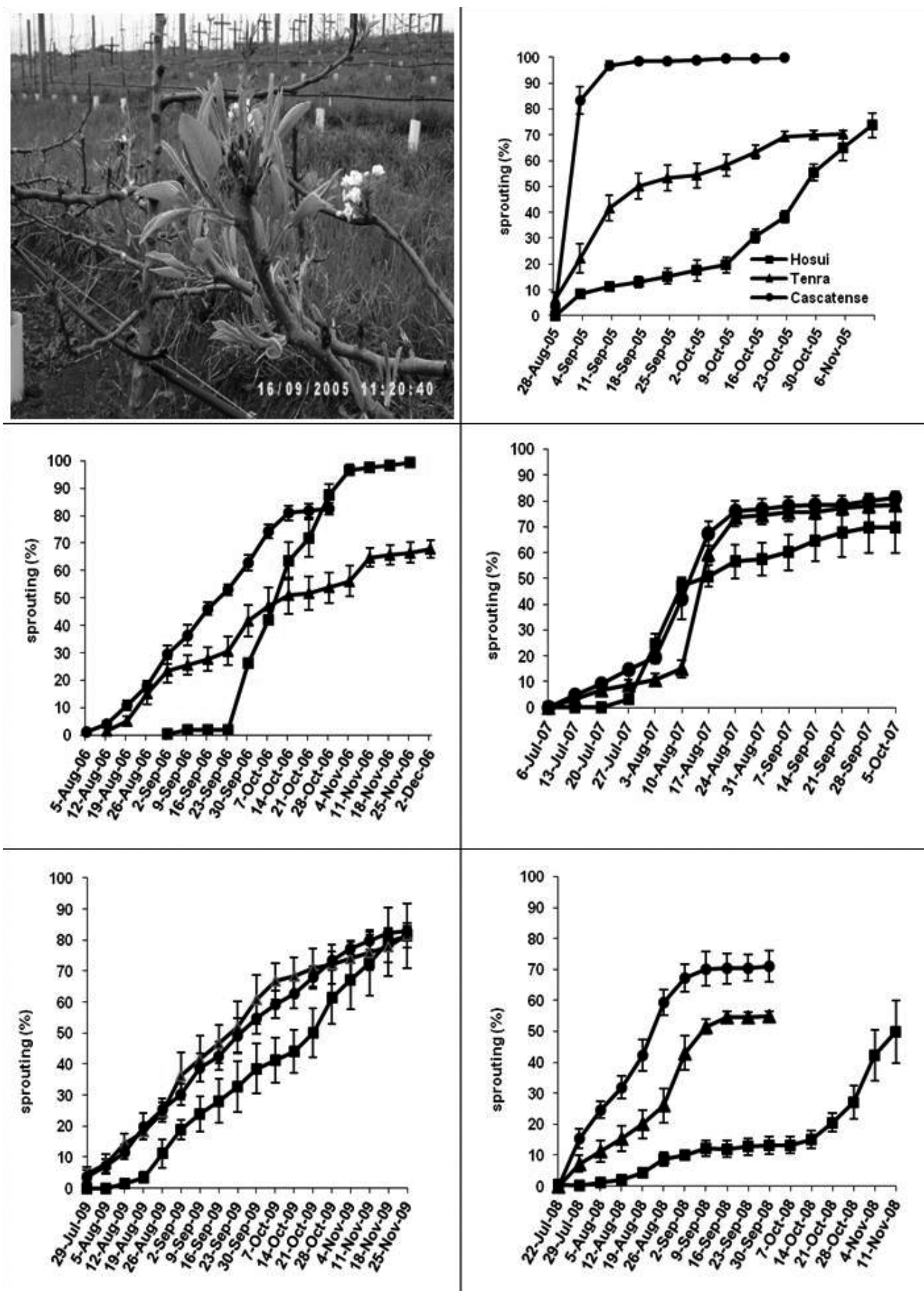

FIGURE 1 - Sprouting (\%) of different pear cultivars grafted on 'CPP' quince rootstock (Guarapuava, Parana, Brazil, 2005-2009). Error bars indicate SD ( $n=5)$. 

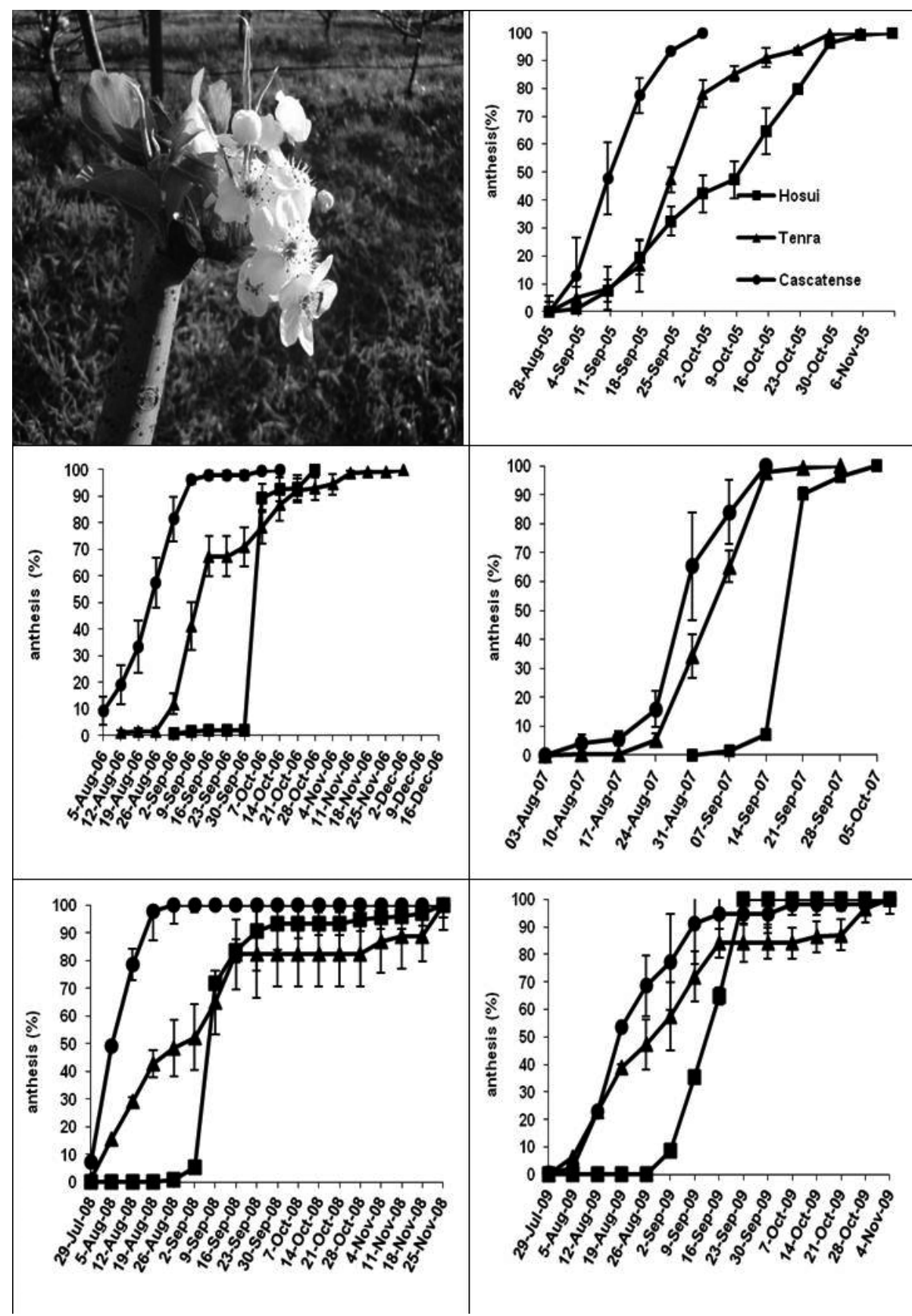

FIGURE 2 - Anthesis (\%) of different pear cultivars grafted on 'CPP' quince rootstock (Guarapuava, Parana, Brazil, 2005-2009). Error bars indicate SD $(n=5)$. 
TABLE 2 - Trunk diameter (mm), Canopy Area per Plant (CAP) e Canopy Area per Hectare (CAH) of pears cultivars grafted on 'CP' quince rootstock (Guarapuava, Parana, Brazil, 2005-2010).

\begin{tabular}{|c|c|c|c|c|c|c|}
\hline \multirow{2}{*}{ Cultivars } & $2004 / 05$ & $2005 / 06$ & $2006 / 07$ & $2007 / 08$ & $2008 / 09$ & $2009 / 10$ \\
\hline & \multicolumn{5}{|c|}{ Trunk diameter $(\mathrm{mm})$} & \\
\hline Cascatense & $27.4 \mathrm{a}$ & $45.5 \mathrm{a}$ & $54.5 \mathrm{a}$ & $61.8 \mathrm{a}$ & $66.6 \mathrm{a}$ & $74.0 \mathrm{a}$ \\
\hline Tenra & $21.7 \mathrm{~b}$ & $35.4 \mathrm{~b}$ & $43.3 \mathrm{~b}$ & $49.8 \mathrm{~b}$ & $58.4 \mathrm{~b}$ & $67.0 \mathrm{ab}$ \\
\hline Hosui & $27.4 \mathrm{a}$ & $35.8 \mathrm{~b}$ & $44.6 \mathrm{~b}$ & $47.1 \mathrm{~b}$ & $52.0 \mathrm{~b}$ & $58.8 \mathrm{~b}$ \\
\hline CV (\%) & 6.87 & 7.46 & 6.52 & 8.26 & 6.88 & 9.52 \\
\hline \multirow[t]{2}{*}{ MSD } & 2.82 & 5.25 & 5.61 & 7.91 & 7.35 & 11.48 \\
\hline & \multicolumn{4}{|c|}{$\operatorname{CAP}\left(\mathrm{m}^{2}\right)$} & & \\
\hline Cascatense & & $1.046 \mathrm{a}$ & $0.748 \mathrm{a}$ & $1.164 \mathrm{a}$ & $1.197 \mathrm{a}$ & $1.226 \mathrm{a}$ \\
\hline Tenra & & $0.704 \mathrm{~b}$ & $0.434 \mathrm{~b}$ & $0.970 \mathrm{ab}$ & $0.974 \quad b$ & $0.978 \mathrm{a}$ \\
\hline Hosui & - & $0.476 \mathrm{~b}$ & $0.300 \mathrm{~b}$ & $0.696 \mathrm{~b}$ & $0.480 \quad \mathrm{c}$ & $0.262 \mathrm{~b}$ \\
\hline $\mathrm{CV}(\%)$ & & 24.47 & 27.49 & 16.45 & 13.10 & 23.21 \\
\hline \multirow[t]{2}{*}{ MSD } & & 0.081 & 0.246 & 0.281 & 0.209 & 0.345 \\
\hline & \multicolumn{4}{|c|}{$\mathrm{CAH}\left(\mathrm{m}^{2}\right)$} & & \\
\hline \multicolumn{2}{|l|}{ Casca } & $2615.0 \mathrm{a}$ & $1863.3 \mathrm{a}$ & $2903.8 \mathrm{a}$ & $2983.5 \mathrm{a}$ & $3063.2 \mathrm{a}$ \\
\hline Tenra & & $1760.0 \mathrm{~b}$ & $1088.0 \mathrm{~b}$ & $2424.0 \mathrm{ab}$ & $2435.2 \mathrm{~b}$ & $2446.4 \mathrm{a}$ \\
\hline Hosui & - & $1190.0 \mathrm{~b}$ & $751.0 \quad \mathrm{~b}$ & $1740.5 \mathrm{~b}$ & $1197.5 \mathrm{c}$ & $654.4 \mathrm{~b}$ \\
\hline CV (\%) & & 24.47 & 27.62 & 16.67 & 13.04 & 23.21 \\
\hline MSD & & 821.29 & 616.74 & 710.78 & 520.43 & 862.92 \\
\hline
\end{tabular}

Means in columns followed by the same letter are not significantly different at the $5 \%$ level using the means separation Tukey's test.

\section{CONCLUSIONS}

1-In Guarapuava conditions, pear trees cv. Cascatense presented the earliest sprouting, flowering and fruit maturation, and the highest fruit weight average and final vegetative growth, followed by cvs. Tenra and Hosui.

2-Pear trees cv.Tenra grafted on quince ' $\mathrm{CPP}$ ' showed the highest accumulated yield (51.6 $\left.\mathrm{t} \mathrm{ha}^{-1}\right)$, followed by the cultivars Cascatense $\left(39.7 \mathrm{tha}^{-1}\right)$ and Hosui $\left(18.7 \mathrm{t} \mathrm{ha}^{-1}\right)$.

3- All pear cultivars showed adequate fruit quality with minimum soluble solids content average of $11.0 \%$ at harvest.

4-The most limiting factor for pear tree production in Guarapuava under organic system was the incidence of pear shoot blight caused by Botriosphaeria dothidea, most often aggressive in pear trees cv. Hosui.

\section{REFERENCES}

BECKER, W.F.; HIROYUKI, L. Ocorrência e patogenicidade de Botryosphaeria dothidea como agente causal da seca de ramos em pereira-japonesa no Estado de Santa Catarina. Summa Phytopathologica, Jaboticabal, v.28, n.2, p.201-203, 2002.

CARRERA, M.; ESPIAU, M.T.; GÓMEZ-APARISI, J. Pear rootstock trial: behavior of 'Conference' and 'Doyenné du Comice' on two quince and five $\mathrm{OHxF}$ selections. Acta Horticulturae, Leiden, n.671, p.481-484, 2005.

CQFS-COMISSÃO DE QUÍMICA E FERTILIDADE DO SOLO-RS/SC. Manual de adubação e de calagem para os Estados do Rio Grande do Sul e de Santa Catarina. 10. ed. Porto Alegre: SBCSNúcleo Regional Sul, 2004. 400p.

EBERT, A.; RAASCH, Z. S. Sistemas de plantio em macieiras. In: EMPASC. Manual da cultura da macieira. Florianópolis: EMPASC, 1987. p.235-265.

FAO. Food and Agriculture Organization of the United Nations. Pear. 2010. Disponível em: $<$ http:// faostat.fao.org $>$. Acesso em: 29 nov. 2010. 
FERREIRA, D. F. Sisvar: um programa para análises e ensino de estatística. Revista Symposium, Lavras, v.6, p.36-41, 2008.

FIORAVANÇO, J.C. A cultura da pereira no Brasil: situação econômica e entraves para o seu crescimento. Informações Econômicas, São Paulo, v.37, n.3, p.52-58, 2007.

MARINI, R.P. Growing pears in Virginia. Virginia Cooperative Extension. 2009. 9p. Disponível em: $<$ http://www.ext.vt.edu/pubs/treefruit/422-017. $\underline{\mathrm{html}}>$. Acesso em: 07 maio 2011.

NAKASU, B.H.; FAORO, I.D. Cultivares. In: QUEZADA, A.C.; NAKASU, B.H.; HERTER, F.G. Pera: produção. Brasília: Embrapa, 2003. p.29-36

POLICARPO, M.; TALLUTO, G.; LO BIANCO, R. Vegetative and productive responses of 'Conference' and 'Williams'pear trees planted at different in-row spacings. Scientia Horticulturae, Oxford, v.109, n.3, p.322-331, 2006.
RIBEIRO, P.A.; BRIGHENTI, E.; BERNARDI, J. Comportamento de algumas cultivares de pereira Pyrus communis L. e suas características nas condições do Planalto Catarinense. Florianópolis: EMPASC, 1991. 53p.

ROBERT, S.C.; STEYN, W.J.; NORTH, M.S. Effect of rootstock on red colour of bi-coloured 'Forelle' pears. Acta Horticulturae, Leiden, n.800, p.625630, 2008.

STERN, R.A.; DORON, I. Performance of 'Coscia' pear (Pyrus communis) on nine rootstocks in the north of Israel. Scientia Horticulturae, Oxford, v.119, n.3, p.252-256, 2009 .

WEBSTER, A.D. Rootstocks for temperate fruit crops: current uses, future potential and alternative strategies. Acta Horticulturae, Leiden, n.557, p.2534, 2001.

WERTHEIM, S.J.; WAGENMAKERS, P.S.; BOOTSMA, J.H.; GROOT, M.J. Orchard systems for apple and pear: conditions for success. Acta Horticulturae, Leiden, n.557, p.209-227, 2001. 